\title{
Morphological and Biochemical Changes of Salmonella hadar Exposed to Aqueous Garlic Extract
}

\author{
Cambios Morfológicos y Bioquímicos de Salmonella hadar Expuestas a Extracto Acuoso de Ajo
}

\author{
${ }^{*}$ H. Belguith; ${ }^{* *}$ F. Kthiri; ${ }^{* * *}$ A. Ben Ammar; ${ }^{* * *}$ H. Jaafoura; " J. Ben Hamida \& ${ }^{* *}$ A. Landoulsi
}

BELGUITH, H.; KTHIRI, F.; BEN AMMAR, A.; JAAFOURA, H.; HAMIDA, J. B. \& LANDOULSI, A. Morphological and biochemical changes of Salmonella hadar exposed to aqueous garlic extract. Int. J. Morphol., 27(3):705-713, 2009.

SUMMARY: The effect on Salmonella hadar growth was investigated using fresh sterile liquid medium (Pronadisa, Hispanlab) containing aqueous garlic extract (AGE) at different concentration $(0,11,12$, and $13 \mathrm{mg} / \mathrm{ml})$. The garlic extract added at these final concentrations had a bacteriostatic effect on Salmonella hadar. The effect of these bacteriostatic concentration of AGE on the growth of the tested serovar, revealed a pattern of inhibition characterized by: (i) a transitory inhibition phase whose duration was proportional to AGE concentration (ii) a resumed growth phase which showed a lower rate of growth than in uninhibited controls, and (iii) an entry into stationary phase at a lower culture density. The minimal inhibitory concentration and minimum bactericidal concentrations were very close, garlic MIC was $12 \mathrm{mg} / \mathrm{ml}$ and the MBC was $14 \mathrm{mg} / \mathrm{ml}$. Among enzymatic activities followed with the API-ZYM system, significant changes during the inhibition phase were detected. These biochemical changes represent an adaptative response towards the garlic stress. Some cellular enzymatic activities disappeared, whereas others were induced or maintained after AGE addition. TEM images of the samples treated with the bacteriostatic concentration of AGE $(12 \mathrm{mg} / \mathrm{ml})$ revealed the rupture of cell walls and nonhomogeneous disposition of cytoplasmic materials within treated bacteria.

KEY WORDS: Allium sativum; Allicin; Antimicrobial effects; Garlic; Salmonella hada; Ultrastructure.

\section{INTRODUCTION}

Antibiotic resistance in food-borne pathogens is a fact, though substantial qualitative and quantitative differences have been observed (Teuber, 1999). Strains of resistant foodborne pathogens to a variety of antimicrobials have become a major health concern (Kiessling et al., 2002) and it could decrease the successful application of control measures on spoilage and pathogen microorganisms, many times leading to the use of less safe, effective or expensive alternatives (Levy, 1997).

The increasingly high number of bacteria that are developing resistance to classical antibiotics (Cohen, 1992; Walsh, 2000; Cole et al., 2002) drives much of the current interest on plant antimicrobial molecules in hope that they mayprovide useful leads into anti-infective drug candidates. Several antimicrobial agents were isolated from plant including secondary metabolites as essential oil and
Terenoides, amongst which can be cited xanthones, benzophenones, coumarins and flavonoids (Nkengfack et al., 2002; Komgeum et al., 2005).

Recently, there has been increasing interest in discovering new natural antimicrobials. This has been also true in food microbiology. Plant products with antimicrobial properties have notably obtained emphasis for possible application in food production in order to prevent bacterial and fungal growth (Fattouch et al., 2007; Lanciotti et al., 2004). Much focus on determining the antimicrobial activity of plant extracts is found in folk medicine (Rios \& Recio, 2005).

Garlic (Allium sativum) is a common food spice widely spread and used in all parts of the world as a spice and herbal medicine for the prevention and treatment of a variety of diseases, ranging from infections to heart diseases.

\footnotetext{
* Unité de Protéomie Fonctionnelle et de Biopréservation Alimentaire. Institut supérieur des Sciences Biologiques Appliquées de Tunis, Tunisie.

** Laboratoire de Biochimie et de Biologie moléculaire. Faculté des Sciences de Bizerte, Tunisie.

${ }^{* * * *}$ Service commun de microscopie électronique a transmission, Faculté de Médecine de Tunis, Tunisie.
} 
Garlic is thought to have various pharmacologic properties and medical applications (Reuter et al., 1996). Garlic is mainly consumed as a condiment in various prepared food (Amagase et al., 2001).

Garlic is a strong antibacterial agent and acts as an inhibitor on both Gram-positive and Gram-negative bacteria including such species as Escherichia, Salmonella, Streptococcus, Staphylococcus, Klebsiella, Proteus and Helicobacter pylori (Ankri \& Mirelman, 1999; Reuter).

These health related properties of garlic are attributed to the organosulfur compounds, thio-2-propene-1-sulfinic acid S-allyl ester, which is usually referred to particularly allicin, the pungent smelling compound. Allicin is produced during the crushing of garlic by the interaction of alliin, the nonprotein amino acid and which is released from mesophyll cells, with the pyridoxal phosphate containing enzyme, alliinase (alliin lyase E.C. 4.4.1.4) of the bundle sheath cells (Miron et al., 2000; Curtis et al., 2004).

Numerous reports indicate that garlic extract has broadspectrum antiobacterial activity (Adetumbi \& Lau 1983), however, the mechanism of this growth inhibition and garlic action is not known.

The mode by which microorganisms are inhibited by plant active molecules seems to involve different mechanisms, which are not elucidated in detail. Even though the antibacterial properties and some of the other positive effects of allicin were already detected in the 1940's, the mechanism of action was not well known, therefore possible application of allicin and its synthetic analogs did not materialize. Two possible mechanisms of allicin action were suggested. One stressed the antioxidant activity of allicin while the other suggested that the particular structure of allicin make it a good candidate for interaction with $\mathrm{SH}$-groups of proteins and other biological compounds (Miron et al.).

Allicin's reactivity with enzymes, its radical-trapping properties and ready membrane permeability, are regarded as the basis of its biological activity (Miron et al., 2002; Rabinkov et al., 1998).

The aim of the present work was first to evaluate the antimicrobial effect of aqueous garlic extract against Salmonella hadar, isolated from Tunisian Turkish meat. Second, to characterize the physiological and biochemical stress responses and finally to investigate the changes in cell morphology using transmission electronic microscopy. Salmonella hadar was chosen as the Gram-negative model organism, as it is one of the major human pathogens and food poisoning cases in the world (Reed, 1993).

\section{MATERIAL AND METHOD}

Bacteria and growth conditions. Salmonella hadar included in this study was recovered from Tunisian Turkish meat, purchased from a fast foods restaurant.

Long-term storage of Salmonella hadar samples was at $-20^{\circ} \mathrm{C}$, in sterile glycerol $(15 \%)$. A preculture was prepared by transfer from this culture to fresh sterile liquid medium (Pronadisa, Hispanlab) and cultivated for $18 \mathrm{~h}$ at $37^{\circ} \mathrm{C}$ with shaking.

Inhibition studies: Overnight cultures of the Salmonella hadar was grown in liquid medium and diluted into $50 \mathrm{ml}$ of fresh sterile broth medium. Aqueous garlic extract was added at various concentrations directly to the flask and turbidity was monitored by measuring the optical density at $600 \mathrm{~nm}$ of the medium.

Preparation of aqueous garlic extract (AGE). Fresh garlic cloves (70 g) were blended in $35 \mathrm{ml}$ sterile distilled water, centrifuged at $5000 \mathrm{rpm}$ and sterilized by filtration $(0.45 \mu \mathrm{m})$. Aliquots were stored at $-20^{\circ} \mathrm{C}$ until required. The method of Miron et al. (2002) was used to quantify the amount of allicin in AGE The approximate allicin content in each preparation was determined spectrophotometrically by reaction with the thiol, 4-mercaptopyridine (Miron et al.; Bakri \& Douglas). Varying volumes of garlic extract were incubated with 4mercaptopyridine (10-4 mM) in $50 \mathrm{mM}$ phosphate buffer, 2 mM EDTA pH 7.2, which results in the formation of a mixed disulphide, 4-allylmercaptothiopyridine and the consequent shift in absorbance at $324 \mathrm{~nm}$ was monitored.

Determination of the minimal inhibitory and bactericidal concentrations (MIC and MBC). The broth dilution method was used to determine the MIC and MBC. Serial twofold dilutions of aqueous garlic extract in $5 \mathrm{ml}$ of broth inoculated with $50 \mu \mathrm{l}$ of fresh precultures (inoculum, 5x108 CFU ml-1). The tubes were incubated at $37^{\circ} \mathrm{C}$ overnight with shaking and the highest dilution where there was no growth was recorded as the MIC. For MBC testing, aliquots $(20 \mu \mathrm{l})$ of broth from tubes containing no growth were plated onto solid medium and again incubated overnight at $37^{\circ} \mathrm{C}$. The highest dilutions in which there were no survivors were recorded as the MBC.

In the above method, controls for each organism were performed using the sterile liquid medium without aqueous garlic extract. MIC and MBC were confirmed by triplicate assays.

Biochemical and enzymatic assays. The changes of different cellular enzymatic activities of treated and nontreated bacteria, collected from the inhibition and the 
exponential growth phase culture, was evaluated using the API-ZYM system (BioMérieux). Cells were harvested, washed twice with cold 5x10-2 mol 1-1 phosphate buffer (pH 7) and resuspended in $0.85 \%$ (w/v) sterile $\mathrm{NaCl}$ solution.

Each API-ZYM gallery was inoculated with two drops of adequate suspension of cells and incubated for $4 \mathrm{~h}$ at $28^{\circ} \mathrm{C}$. The galleries were then activated by adding one drop of ZYM-A and ZYM-B reagents and after $5 \mathrm{~min}$, values ranging from 0 to 5 in relation to the color developed in each enzymatic reaction, were visually assigned by means of the color chart supplied with the system.

Electron microscopy. Samples for examination were collected from the inhibition and the exponential growth phase culture (treated cells) and the exponential growth phase culture (untreated cells). After the supernatant was discarded (10 $000 \mathrm{~g}$ for $5 \mathrm{~min}$ at $4^{\circ} \mathrm{C}$ ), the Salmonella hadar cells pellet was prefixed with $3 \%$ glutaraldehyde in $0.2 \mathrm{M}$ sodium cacodylate buffer ( $\mathrm{pH}$ 7.4). Samples were postfixed for $2 \mathrm{~h}$ with $1 \%$ osmium tetroxide (v/v) in $0.1 \mathrm{M}$ sodium phosphate buffer ( $\mathrm{pH}$ 7.4). After fixation the sample was centrifuged at $1800 \mathrm{~g}$ for $2 \mathrm{~min}$, the pellet washed three times in $0.2 \mathrm{M} \mathrm{Na}$ cacodylate buffer ( $\mathrm{pH}$ 7.4). Samples were dehydrated in a graded series of ethanol. The TEMs were taken with a JEOL1010 electron microscope operating at $80 \mathrm{kV}$.

\section{RESULTS}

Effect of aqueous garlic extract on Salmonella growth. In order to study the effect of the AGE, different concentrations were tested. No effect on the different cell growth curves was observed when we added an AGE to a final concentration less than $11 \mathrm{mg} / \mathrm{ml}$ (mean $89.1 \mathrm{mg} / \mathrm{ml}$ of allicin). So we had studied the effect of garlic extract added to a final concentration ranging from 11 to $13 \mathrm{mg} / \mathrm{ml}$.

Compared with the control cell suspensions lacking garlic extract, we observed a modification of the classical Salmonella hadar growth curve. Figure 1 shows the basic phenomena observed in the inhibition of cell growth by aqueous garlic extract.

The addition of AGE to these final concentrations at cell density of 0.05 induces the apparition of an inhibition phase in the Salmonella hadar growth curves. After this inhibition phase, cell growth resumed but at a rate inferior to the control cell suspensions. In addition, cultures exposed to AGE entered stationary phase at a cell density substantially lower than that of the control culture. This phenomenon seems to be due to the decrease in the number of viable bacteria.

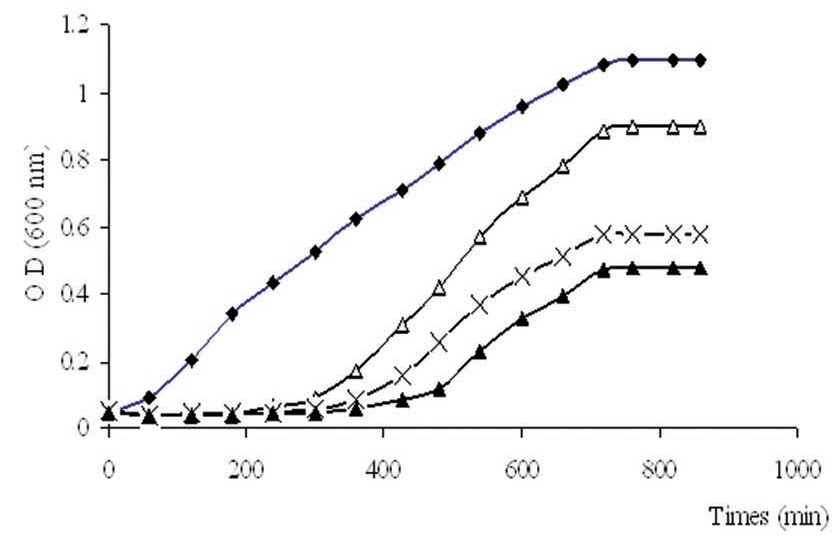

Fig. 1. Growth curves of Salmonella hadar serovar in liquid medium (Pronadisa, Hispanlab) at $37^{\circ} \mathrm{C}$ treated with different concentrations of aqueous garlic extract. Samples were collected every $20 \mathrm{~min}$ and culturable counts were performed as described in "Material and method". Aqueous garlic extract concentrations $\left(\mathrm{mg} \mathrm{ml}^{-1}\right)$ : $(\bullet)$ : $0 ;(\mathbf{\Delta}): 11 ;(\mathrm{x}) 12 ;(\mathbf{\Delta}): 13$.

The effect of increasing AGE concentration on bacterial growth is indicated in figure 1. As the aqueous garlic extract concentration was increased from 11 to $13 \mathrm{mg} \mathrm{ml}-1$ (89.1 to $97.2 \mathrm{mg} \mathrm{ml-1}$ of allicin), the duration of the inhibition phase increased, the rate of the growth after inhibition decreased and the cell density at which stationary phase was entered also decreased. The duration of the inhibition phase was proportional to the aqueous garlic extract concentration and variable according to the different salmonella serovars tested. The garlic extract added at these final concentrations had a bacteriostatic effect on Salmonella hadar.

In order to study the proportionality of the relationship between the amount of active substance and diameter of inhibition zone, garlic extract $(20 \mu 1)$ or dilutions were pipetted onto a stack of six $6 \mathrm{~mm}$ diameter Wattman-paper discs cut with a hole-punch. The size of the inhibition halo was clearly proportional to the amount of AGE applied, and it showed a linear relationship when plotted against the log of the diameter of the inhibition zone (Fig. 2).

Determination of MIC and MBC. Table I shows the MIC and $\mathrm{MBC}$ values determined by broth dilution and expressed in terms of the garlic extract concentration and the deduced allicin concentration. MIC was about $12 \mathrm{mg}$ ml-1 garlic (estimated $9.7 \mu \mathrm{g} \mathrm{ml-1}$ allicin), whereas, the MBC value was $14 \mathrm{mg} \mathrm{ml-1}$ garlic (mean $11.3 \mu \mathrm{g}$ ml-1 of allicin).

Biochemical changes of Salmonella hadar. In order to assess biochemical changes induced by AGE during the Salmonella hadar growth, several bacterial enzymatic activities were analyzed during the inhibition (treated bac- 
teria) and the exponential phase cells culture (treated and untreated bacteria).

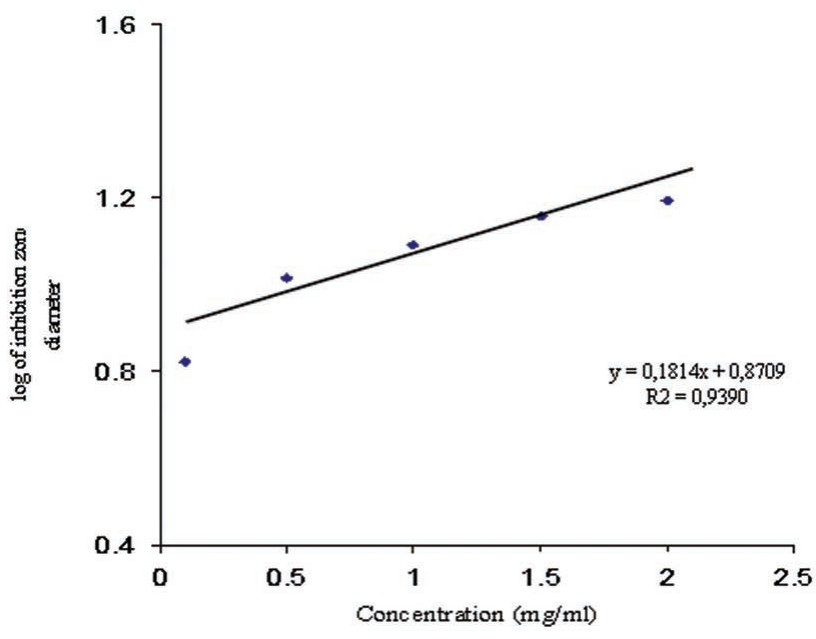

Fig. 2. Study of the relationship between the amount of active substance and the diameter of inhibition zone. Garlic aqueous extract $(20 \mu \mathrm{l})$ or dilutions were pipetted onto a stack of six $6 \mathrm{~mm}$ diameter Wattman-paper discs cut with a hole-punch.
Among enzymatic activities followed with the APIZYM system, some enzyme activities showed significant changes. Compared with the untreated cells, we observed that some enzyme activities were maintained at low level, others were already induced and others inhibited (Fig. 3). Our results showed that during the inhibition phase, most Salmonella hadar enzyme activities were totally inhibited such as esterase (C 4), Leucine aryllamidase, a-glucosidase or maltase. During the exponential cell growth phase treated bacteria present different enzymatic activities, compared to the untreated cells. We observed that some enzyme activities are positively affected, such as Esterase (C 4), esterase lipase (C 8) activities, but other enzyme such as a-glucosidase is slightly inhibited, whereas, the a-mannosidase was activated.

These results showed that the different enzyme activities did not present the same biochemical changes, during the inhibition, as well as, during the exponential cell growth phase.

Garlic stress-associated morphological changes. Electron microscopic examination of stressed cells confirmed the heterogeneous nature of the cellular suspension when compared with nontreated exponential phase cells (Fig. 4 a).

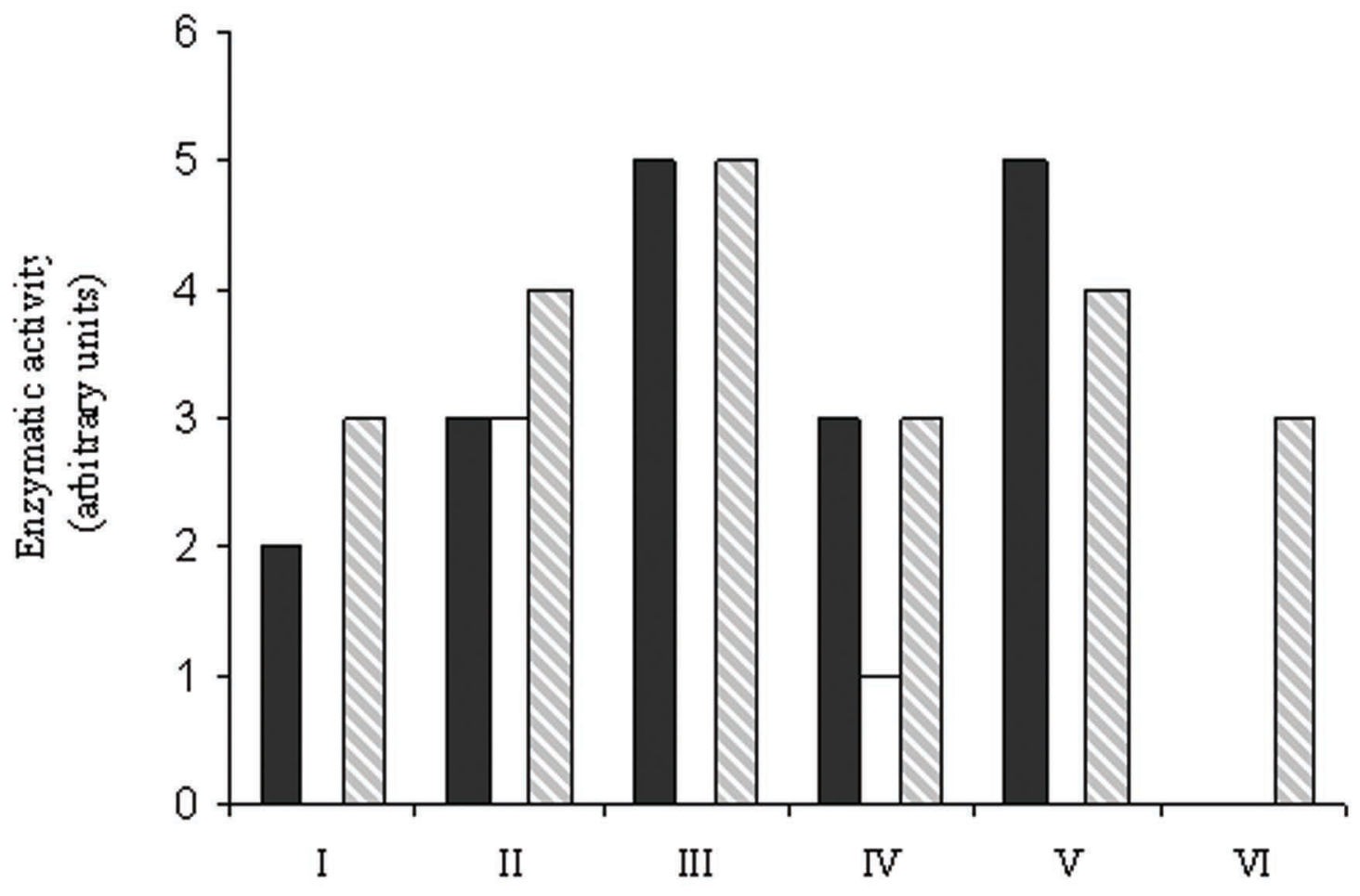

Fig. 3. Changes in some enzymes activity levels of Salmonella cells during A.G.E. treatment (12 mg ml-1). I. Esterase (C 4), II. Esterase lipase (C 8), III. Leucine arylamidase, IV. Naphtol-AS-BI-phosphohydrolase, V. alpha-glucosidase. VI. alpha-mannosidase. ( $\square$ ). Control bacteria; ( $\square$ ). Treated bacteria (inhibition phase); ( $\square$ ) Treated bacteria (exponential phase). 
BELGUITH, H.; KTHIRI, F.; BEN AMMAR, A.; JAAFOURA, H.; HAMIDA, J. B. \& LANDOULSI, A. Morphological and biochemical changes of Salmonella hadar exposed to aqueous garlic extract. Int. J. Morphol., 27(3):705-713, 2009.

Table I. Inhibitory effect (MIC and MBC) of garlic extract on Salmonella hadar.

\begin{tabular}{lcccc}
\hline & MIC & \multicolumn{2}{c}{ MBC } \\
\hline Salmonella. hadar (287) & {$[$ AGE] $\mathrm{mg} / \mathrm{ml}$} & [Allicin] $\mu \mathrm{g} / \mathrm{ml}$ & [AGE] $\mathrm{mg} / \mathrm{ml}$ & {$[$ Allicin] $\mu \mathrm{g} / \mathrm{ml}$} \\
& 12 & 9.7 & 14 & 11.3 \\
\hline
\end{tabular}

The general morphology and the ultrastructure of the cell envelope of untreated exponential phase cells (Figs. 4, a, b, c and d) are quite similar to those of Gram-negative rods in general. Figure 3 illustrates morphological changes in treated Salmonella inhibition phase cells. In these treated cells with AGE at $12 \mathrm{mg} \mathrm{ml}-1$, the cytoplasm was disorganized and the inner and the outer membrane were separated, the integrity of the outer membrane, however was not maintained in some cases. We observed some rodlike projections that appeared on the surface of the OM. These projections seemed to involve the outer membrane of the cell wall.
These projections became more numerous and longer with increasing concentrations of AGE (Figs. 5 b and c) and they probably reflect the breakdown of the integrity of the cell envelope.

The overall structure of the projections (Figs. 4 and 5) was that of a thin rod. Their diameter, length, number and the size was variable. Cross sections (Fig. 4) showed that the projections were cylindrical rather than cuts from longitudinal folds. There was no consistent internal structure visible in the projections, and in this respect, they resembled simple lipid micelles.

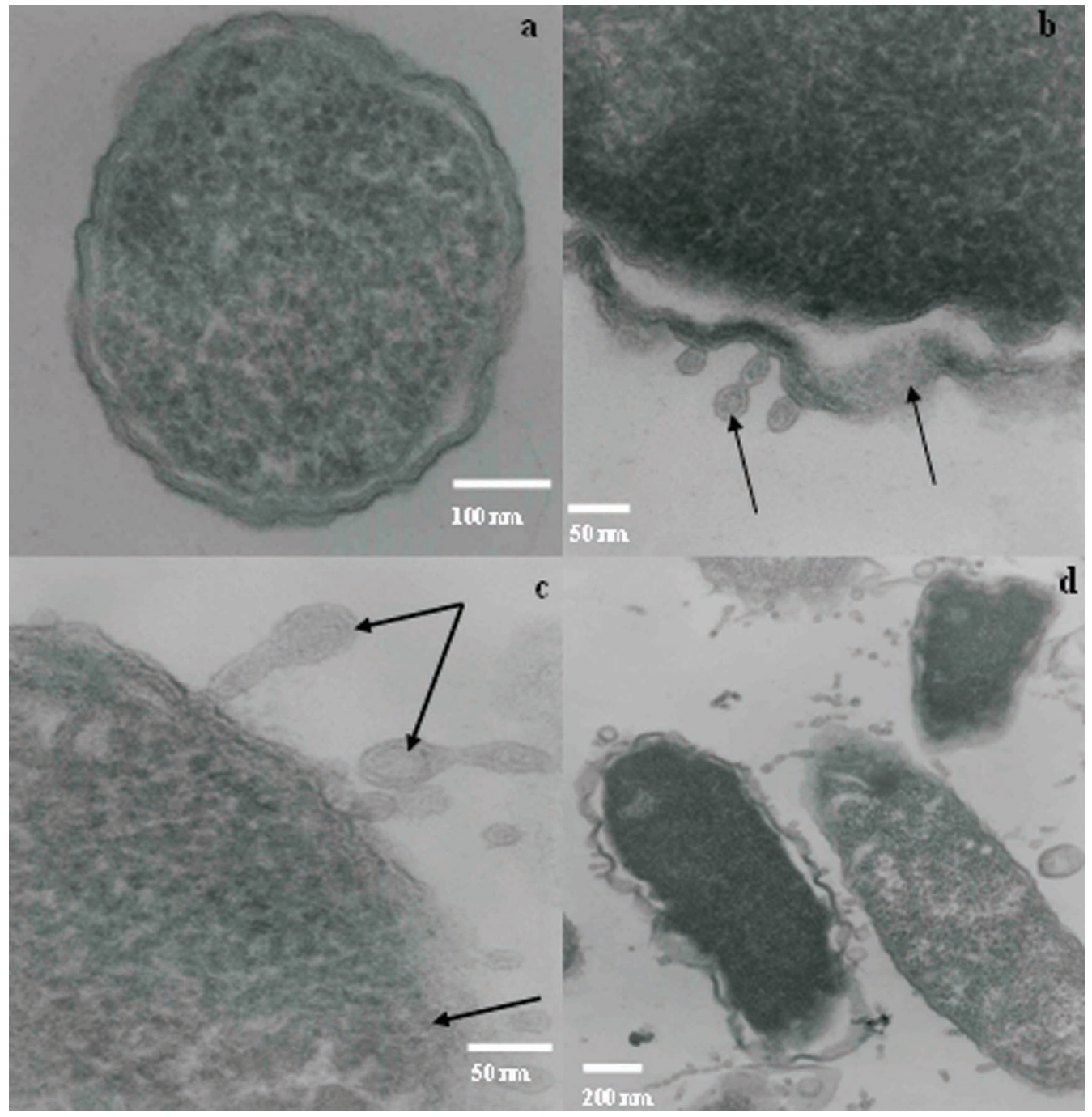

Fig. 4. Effect of Aqueous garlic extract on the ultrastructure of Salmonella hadar as demonstrated by transmission electron microscopy. Cells from inhibition growth phase, and exponential growth phase were analyzed.

(a) control samples, from exponential growth phase; (b,c,d) cells treated with garlic extract 12 $\mathrm{mg} / \mathrm{ml}$, from inhibition growth phase. 


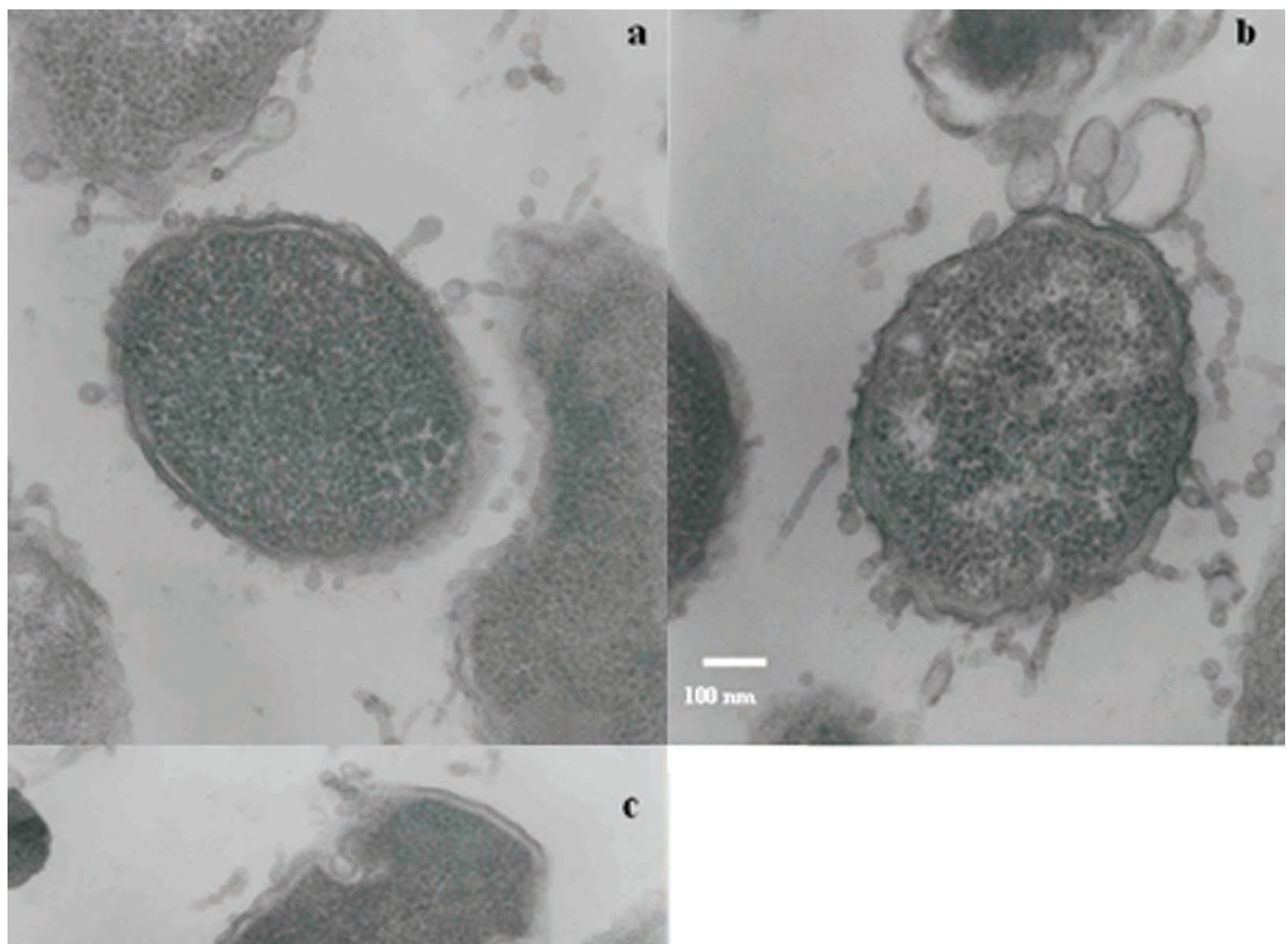

Fig. 5. Effect of aqueous garlic extract on the ultrastructure of Salmonella hadar as demonstrated by Transmission electron microscopy. Treated cells from the resumed secondary logarithmic growth phase were analyzed by TEM.

\section{DISCUSSION}

In this study, a marked inhibitory effect of garlic against Salmonella hadar, which has been also described against other bacteria, was observed and confirmed. The phenomenon of inhibition is characterized by: i) an inhibition phase observed during the lag phase which appears longer than that observed in the cell growth control, the same result was described by Feldberg et al. and O' Gara et al. (2000), ii) a resumed secondary logarithmic growth rate less than the original rate of growth. These observations confirm those described by Feldberg et al. The duration of inhibition was proportional to the final aqueous garlic extract concentration, there was a simple linear relationship between inhibition activity and AGE amount.

After this inhibition phase, cells were able to overcome the inhibition and resume growth, which suggests that they were able to metabolize the allicin to noninhibitory compound. Although aqueous garlic extract at these concentrations is bacteriostatic rather than bactericidal, the observation that the resumed growth rate is substantially lower than the uninhibited-culture growth rate suggests that the inhibited cells are not totally able to recover from 
aqueous garlic extract inhibition. The lower secondary growth rate could indicate either the presence of some unrepaired lesion in the cells or the depletion of limiting nutrients from the medium during the inhibition phase.

The values of MIC and MBC were very close of those described in the literature for other Gram-negative stains, but they are lower than the Gram-positive stains (Bakri \& Douglas 2005).

In this study, we have shown that the different Salmonella serovars collected in the inhibition or in the exponential growth phase, can undergo morphological and biochemical changes when exposed to AGE. The assay gave good proportionality in serial dilution (Fig. 2).

The molecular mechanism of garlic antimicrobial activities is not well known compared to antibiotics and organic acids. Various authors have hypothesized that organic acids may damage outer or cytoplasmic membrane, hinder macromolecular synthesis or denature proteins and DNA (reviewed by Ricke, 2003). Effect of monolaurin may be similar. The increase of permeability of bacterial membranes may also potentiate the effect of other antimicrobial agents as shown with lactic acid and sodium laurylsulphate (Al komi et al., 2000). They have found that bacteria maintained integrity of membranes in cells treated with caprylic and lauric acid or monolaurin. The increase in $\mathrm{K}^{+}$permeability of the cytoplasmic membrane, which usually leads to dissipation of membrane potential (Katsu et al., 1984), was not observed.

Feldberg et al. (1988) described that the in vitro mechanism of Salmonella typhimirium inhibition growth by allicin at bacteriostatic concentrations ( 0.2 to $0.5 \mathrm{mM})$ was found to be due to a delayed and partial inhibit of DNA and protein synthesis and an immediate inhibition of RNA synthesis, suggesting that this is the primary target of allicin action.

To elucidate the mode of action of AGE, morphological changes in Salmonella hadar occurring upon AGE treatment were examined by transmission electronic microscopy. In contrast to control bacteria with intact cell membranes (Figs. 4 and 5), AGE-treated bacteria showed a remarkable lysis of the cell membrane and nonhomogeneous disposition of cytoplasmic materials.

Aqueous garlic extract acts mainly on Gram-negative bacteria, and their outer membrane (OM), which is absent in Gram-positive bacteria, seems to be one of its main targets. It seems the AGE alters the ultrastructure of the OM, whereas changes are not seen in the cytoplasmic membrane.
The characteristic effect of AGE on the morphology of Salmonella seems to be the formation of various kinds of projections and blebs on the outer membrane of the cell envelope.

Alterations of other components of the cell are seen at $12 \mathrm{mg} / \mathrm{ml} \mathrm{AGE}$, which probably causes extensive damage. These findings are in good general agreement with a clear damage on the ultrastructure of Gram-negative bacteria.

These findings are consistent with corresponding studies in Salmonella typhimurium, in which Louatmaa et al. (1976) also found that treated bacteria by polymyxin present these projections. They described that in thin sections, these projections appeared to be consisted of a unit membrane clearly continuous with the whole OM, without participation of the entire cell envelope.

Our results suggest that these projections are involved in the OM. alterations caused by AGE and may explain some of the antibacterial garlic effects. The physical cause of these OM alterations in morphology may be due to the loss of certain outer membrane protein and /or lipolpolysaccharids (Irvin et al., 1975).

The change of different cellular enzymatic activities during AGE treatment may also form a part of bacteria's strategy against stress condition. To sum up, the reported results shed new light on the behavior of pathogenic Gramnegative bacteria under AGE stress. This antibacterial agent triggers several morphological and biochemical changes enabling Salmonella hadar to escape the deleterious effects of garlic. Moreover, the natural resistance of such cells to garlic compounds is unknown. Work is in progress in our laboratory to determine the mechanisms of garlic toxicity and to identify molecules involved in the OM alteration.

ACKNOWLEDGEMENT. We are indebted to Professor Ben Aissa from The Laboratory of Water and Food Borne Surveillance of the Tunisian Pasteur Institute, for the gift of the Salmonella serovars. We thank Professor Gaja Monji and Aissi Ahmed for their critical reading and revision of the manuscript.

BELGUITH, H.; KTHIRI, F.; BENAMMAR, A.; JAAFOURA, H.; HAMIDA, J. B. \& LANDOULSI, A. Cambios morfológicos y bioquímicos de Salmonella hadar expuestas a extracto acuoso de ajo. Int. J. Morphol., 27(3):705-713, 2009.

RESUMEN: El efecto sobre el crecimiento de Salmonella hadar fue investigado utilizando un medio líquido estéril fresco (Pronadisa, Hispanlab) conteniendo el extracto acuoso de ajo (EAA) en diferentes concentraciones $(0,11,12$ y $13 \mathrm{mg} / \mathrm{ml})$. El extracto de ajo añadido con estas concentraciones tuvo un efecto 
bacteriostático sobre Salmonella hadar. La prueba serovar reveló un patrón de inhibición caracterizado por: (i) una fase de inhibición transitoria cuya duración fue proporcional a la concentración de EAA, (ii) una reanudación de la fase de crecimiento, la cual mostró una tasa más baja de crecimiento que controles sin inhibición, y (iii) una ingreso en fase estacionaria con una menor densidad de cultivo. La concentración mínima inhibitoria (CMI) y la concentración mínima bactericida (CMB) fueron muy cercanas, la CMI de ajo fue de $12 \mathrm{mg} / \mathrm{ml}$ y la CMB fue de $14 \mathrm{mg} / \mathrm{ml}$. Las actividades enzimáticas seguidas con el sistema API-ZYM, mostraron cambios significativos durante la fase de inhibición. Estos cambios bioquímicos representan una respuesta adaptativa al estrés del ajo. Algunas actividades enzimáticas celulares desaparecieron, mientras que otras fueron inducidas o mantenidas después de la adición de EAA. Las imágenes de MET de las muestras tratadas con la concentración del bacteriostático EAA $(12 \mathrm{mg} / \mathrm{ml})$ revelaron la ruptura de las paredes celulares y la disposición no homogénea de materiales citoplasmáticos dentro de las bacterias tratadas.

PALABRAS CLAVE: Allium sativum; Alicina; Efectos antimicrobianos; Ajo; Salmonella hadar; Ultraestructura.

\section{REFERENCES}

Adetumbi, M. A. \& Lau, B. H. Allium sativum (garlic) a natural antibiotic. Med. Hypotheses, 12(3):227-37, 1983.

Alakomi, H. L.; Skytta, E.; Saarela, M.; Mattila-Sandholm, T.; Latva-Kala, K. \& Helander, I. M. Lactic acid permeabilizes Gram negative bacteria by disrupting the outer membrane. Appl. Environ. Microbiol., 66:2001-5, 2000 .

Amagase, H.; Petesch, B. L.; Matsuura, H.; Kasuga, S. \& Itakura, Y. Intake of garlic and its bioactive components. J. Nutr., 131:955S-62S, 2001.

Ankri, S. \& Mirelman, D. Antimicrobial properties of allicin from garlic. Microbes Infect., 1:125-9, 1999.

Bakri, I. M. \& Douglas, C.W. Inhibitory effect of garlic extract on oral bacteria. Arch Oral. Biol., 50(7):645-51, 2005 .

Cohen, M. L. Epidemiology of drug resistance: implications for a post-antimicrobial era. Science, 257:1050-5, 1992.

Cole, A. M.; Hong, T.; Nguyen, T.; Zhae, C.; Bristol, G.; Zack, J. A.; Waring, A. J.; Yang, O.O. \& Lehler, R. I. Retrocyclin: a primate peptides that protects defense responses to infection. Nature, 411:826-33, 2002.

Curtis, H.; Noll, U.; Störmann, J. \& Slusarenko, A. J. Broad- spectrum activity of the volatile phytoanticipin allicin in extacts of garlic (Allium sativum L.) against plant pathogenic bacteria, fungi a,d Oomycetes. Physiol. Mol. Plant Pathol., 65:79-89, 2004.

Fattouch, S.; Caboni, P.; Coroneo, V.; Tuberoso, C. I. G.; Angioni, A.; Dessi, S.; Marzouk, N. \& Cabras, P. Antimicrobial activity of Tunisian quince (Cydonia oblonga Miller) pulp and peel polyphenolic extracts. $J$. Agric. Food Chem., 55:963-9, 2007.

Feldberg, R. S.; Chang, S. C.; Kotik, A. N.; Nadler, M.; Neuwirth, Z.; Sundstrom, D. C. \& Thompson, N. H. In vitro mechanism of inhibition of bacterial growth by allicin. Antimicrob. Agents Chemother., 32:1763-8, 1988.

Irvin, R. T.; Chatterjee, A. K.; Sanderson, K. E. \& Costerton, J. W. Comparison of the cell envelope structure of a lipopolysassharide-defective (Heptose-Deficient) strain and a smooth strain of Salmonella typhimurium. J. Bacteriology, 124(2):930-41, 1975.

Katsu, T.; Tsuchiya, T. \& Fujita, Y. Dissipation of membrane potential of Escherichia coli cells induced by macromolecular polylysine. Biochem. Biophys. Res. Comm., 122:401-6, 1984.

Kiessling, C. R.; Bennit, M. H. J.; Loftis, M.; Kissling, V. W.; Data, A. R. \& Soos, J. N. Antimicrobial resistance of food retailed Salmonella isolates. J. Food Prot., 65:603-8, 2002.

Komgeum, J.; Meli, A. L.; Manfou, R. N.; Lontsi, D.; Ngounou, F. N.; Kuete, V.; Kamdem, H. W.; Tane, P.; Ngadjui, B. T.; Sondengam, B. L. \& Connolly, J. D. Xanthones from Garcinia smeathmannii (Oliver) and their antimicrobial activity. Phytochemistry, 66:1713-7, 2005.

Lanciotti, R.; Gianotti, A.; Patrigani, N.; Belleti, N.; Guerzoni, M. E. \& Gardini, F. Use of natural aroma compounds to improve shelf-life of minimally processed fruits. Trends Food Sci. Technol., 15:201-8, 2004.

Levy, S. W. Antibioticresistance: origins, evolution, selection and spread. Chichester, Ciba Foundation Symposium, 1997. pp.1-14.

Lounatmaa, K.; Makela, P. \& Sarvas, M. Effect of polymyxin on the ultrastructure of the outer membrane of wild-type and polymyxin-resistant strains of Salmonella. J. Bacteriology, 127(3):1400-7, 1976.

Miron, T.; Feigenbalt, G.; Weiner, L.; Mirelman, D.; Wilchek, 
M. \& Rabinikov, A. A spectrophotometric assay for allicin, allin and alliinase (alliin-lyase) with a chromogenic thiol: Reaction of 4-mercaptopyridine with thiosulfinates. Analytical Biochem., 307:76-83, 2002.

Miron, T.; Rabinikov, A.; Mirelman, D.; Wilchek, M. \& Weiner, L. The mode of action of allicin: Its ready permeability through phospholipid membranes may contribute to its biological activity. Biochim. Biophys. Acta., 1463:20-30, 2000.

Nkengfack, A. E.; Mkounga, P.; Meyer, M.; Fomum, Z. T. \& Bodo, B. Globulixanthones C, D and E: Three prenylated xanthones with antibacterial properties from the root bark of Symphonia globulifera. Phytochemistry, 61:181-7, 2002.

O'Gara, E. A.; Hill, D. J. \& Maslin, D. J. Activities of garlic oil, garlic powder, and their diallyl constituents against Helicobacter pylori. Appl. Environ. Microbiol., 66:226973, 2000 .

Rabinkov, A.; Miron, T.; Konsrantinovski, L.; Wilchek, M.; Mirelman, D. \& Weiner, L. The mode of action of allicin: trapping of radicals and interaction with thiol containing proteins. Biochim. Biophys. Acts, 1379:233-44, 1998.

Reed, G. H. Foodborne illness (Part I)-Staphylococcal ("Staph") food poisoning. Dairy, Food and Environmental Sanitation, 13(11):642, 1993.

Reuter, H. D.; Koch, H. P. \& Lawson, D. L. Therapeutic effects and applications of garlic and its preparations. In: Garlic: The Science and Therapeutic Applications of Allium sativum L. and Related Species, ${ }^{\text {nd }}$ Ed. Koch, H. P. \& Lawson, D. L. (Eds.). Baltimore, William and Wilkins, 1996. pp.135-212.

Ricke, S. C. Perspectives on the use of organic acids and short chain fatty acids as antimicrobials. Poult. Sci., 82:632-9, 2003.

Rios, J. L. \& Recio, M. C. Medicinal plants and antimicrobial activity. J. Ethnopharmacol., 100:80-4, 2005.

Teuber, M. Spread of antibiotic resistance with food-borne pathogens. Cellular and Molecular life Science, 56:75563, 1999.

Walsh, C. Molecular mechanism that confer antibacterial drug resistance. Nature, 406:775-81, 2000.
Correspondence to:

Belguith Hatem

Unité de Protéomie Fonctionnelle et de Biopréservation Alimentaire Institut supérieur des Sciences Biologiques Appliquées de Tunis

9 Avenue Zouhaïr Essafi. 1007

Tunis

TUNISIE

Fax 21672590566.

Email: hatem.belguith@fsb.rnu.tn

Received : 17-04-2009

Accepted : 11-08-2009 
